the film industry. All inquiries should be made to M. Michaelis (honorary secretary), 51 Fitzjohn's Avenue, London, N.W.3.

\section{Prehistory in the Deccan}

So long ago as 1930, in the September number of Antiquity, Mr. M. C. Burkitt made an attempt to set out in some order the early archæological discoveries of south-east India. The bases for the study were the finds and notes made during a long period of years by Mr. L. A. Cammiade over a wide area of country including the districts along the lower reaches of the Godavari River. Actually, the finds made near this river were all from the surface and could not be accurately dated. They were, however, mostly microlithic in character; but it was clear that many ages were represented. Mr. H. D. Sankalia has now published a short article, "Studies in Prehistory of the Deccan (Maharashtra) : a Survey of the Godavari and the Kadva near Niphad" (Bull. Deccan Coll. Res. Inst., 4, No. 3) which, while not taking us much further, has a certain interest. Briefly, the Godavari has, in places, eut down through the trap to a low level, having previously deposited on the trap a series of gravels in which Mr. Sankalia has discovered a few artefacts in situ. Unfortunately, the illustrations are not very good, and it does not appear that any outstanding finds have been made, but $\mathrm{Mr}$. Sankalia is to be congratulated on having started an investigation which eventually may prove to be of considerable interest. It must always be remembered that the well-known micro-industries of the rock shelters in the Central Provinces of India, far from corresponding to the Mesolithic industries of Britain, are apparently for the most part postChristian in date. At the same time there are postMiddle Stone Age finds of small implements in the Cammiade collection which probably do date to Late Pleistocene times. Further work by Mr. Sankalia may help to elucidate these problems.

\section{St. John's Wort in Australia}

ST. JoHn's WORT (Hypericum perforatum var. angustifolium), introduced into Australia in about 1880 as a garden plant, is now a serious weed in many parts of that country. Besides reducing the carrying capacity of the pasture, stock may become affected with 'wort dermatitis', for the hypericin in the plant acts on the nervous system, rendering the exposed non-pigmented areas of their skin photosensitive. Control measures of various kinds are being tried, including improvement of the pasture by sowing competitive species, chemical treatment and the liberation of insect parasites. Some account of the success attending these trials is given in recent publications of the Australian Council for Scientific and Industrial Research. Bulletin 151 consists of a paper by R. M. Moore and A. B. Cashmore, who have investigated the problem from the agrostologist's point of view, while the entomological aspect is specially dealt with by F. Wilson and T. G. Campbell in the Council's Journal (16, p. 45). The results are most promising. Subterranean clover (Trifolium subterranean), a winter-growing annual, proved an efficient competitor with St. John's wort, and in association with perennial grasses, such as Phalaris tuberosa or Lolium perenne, almost completely eradicated the weed and provided a productive and nutritious pasture. The mixture is best sowr with a dressing of superphosphate after a summer fallow, a dense pasture being afterwards maintained by regular top-dressings and a rotational system of grazing. The use of dark-coloured stock is also recommended as they are less prone to wort dermatitis. For entomological control, three insects have been established in Australia, two leaf-eaters, Chrysolina hyperici and $C$.gemellata, and a root-boring Buprestid, Agrilus hyperici. The prospects of success are good, particularly with Agrilus, as it is remarkably free from predators and parasites, but the Chrysolina species have a high reproductive rate, and judging from experience in France, all three insects can play a useful part in the control of the weed.

\section{Stellar Spectrophotometry in the U.S.S.R.}

Two recent publications (Bull. Acad. Sci. Georgian S.S.R., 3, No. 6, p. 509 ; No. 7, p. 657; 1942) give news that astrophysics still flourishes just beyond the high-water mark of the German advance into southern Russia. At Abastumani Observatory an extensive programme of photo-electric colorimetry of $B 8-B 9$ stars was begun in the summer of 1940 and is still in progress. The colours of all stars of these spectral types brighter than 7.5 mag., lying in a zone within $20^{\circ}$ of the galactic equator, are being measured with an antimony-cæsium photo-cell attached to a $33 \mathrm{~cm}$. reflector. Colour filters give effective wavelengths of $4060 \mathrm{~A}$. and $5280 \mathrm{~A}$., the resulting colour equivalents being on a base-Iine slightly longer than ordinary photographically determined colour indexes. The greater sensitivity, range and stability of the antimony-cresium cell enables the Russian observers, V. Nikonov and E. Brodskaja, to obtain observations of which the probable error is less than \pm 0.01 mag. for stars brighter than the sixth magnitude, and less than $\pm 0.02 \mathrm{mag}$. for the fainter stars. When full results of this programme are available, they should add greatly to our knowledge of the selective absorption of light by interstellar matter situated fairly close to the sun.

Meanwhile, a vexed point regarding the colour temperature of $\alpha^{2}$ CVen is being investigated at Mt. Kanobili. Thirty-three observations of the star taken in the spring and summer of 1941 show a maximum variation of colour temperature of $2,000^{\circ}$, which agrees better with the spectrum changes than the value of $10,000^{\circ}$ found by Tai (Mon. Not. Roy. Astro. Soc., 100,$94 ; 1939)$. A puzzling feature of the observations is that the star is bluer at minimum than at maximum, a characteristic which differentiates it sharply from such intrinsic variables as Cepheids and long-period variables. Observations are being continued at Abastumani in happier circumstances than any obtaining since the inception of the programme.

\section{South African Institute for Medical Research}

THE annual report for 1942 of the South African Institute for Medical Research in Johannesburg indicates that this progressive Institute is playing its full part in the war effort. Staffed by 153 Europeans and 118 Africans, its activities are wide. In 1942, its buildings, which were no longer adequate to the large demands for serum for civilians and for army needs, were enlarged; a branch laboratory was established at Bloemfontein. The erection of a large plant for the manufacture of dried human and other serum was made possible by a grant of $£ 10,000$ from Sir Ernest Oppenheimer and the Anglo-American Corporation of South Africa. The production of 
vaccines and sera for the troops has been very greatly increased; staff are being trained for the administration of military hospitals and for their laboratories, and two mobile laboratories and nineteen military hospital laboratories have been established in the Union. Special military medical problems are being investigated. Other war activities of the Institute include vitamin assays, food analyses for military needs, the production of anti-gas-gangrene serum, the study of insect vectors of disease, plague, relapsing fever, typhus and yellow fever. The list of other researches being done is impressive, and the Institute's routine diagnostic work is evidently one of its most important activities.

\section{Rapid Disappearance of Smallpox}

According to the May issue of the Statistical Bulletin, the organ of the Metropolitan Life Insurance Company of New York, in 1942 for the first time in the history of the United States the number of smallpox cases fell below 1,000. Eleven States were entirely free from the disease, and three other States reported only one case each. Texas alone had more than 100 cases. During the whole year there were less than ten smallpox deaths. In Canada there were only six cases and no deaths. The 897 cases of smallpox reported in the United States in 1942 showed a marked decline from the previous low record of 1,446 cases in 1941 and were only a fraction of the number for 1940,1939 and 1938, when the cases numbered $2,797,9,877$ and 14,977 respectively. In an outbreak of 65 cases in Pennsylvania, the patients had either not been vaccinated or had long outlived their immunity. Apart from 13 unvaccinated school-children, the victims were past middle age.

\section{Production of Rubber in Europe}

A SHORT notice of an article in Agricultura (128, Dec. 1942) entitled "La producción de caucho en Europa" appears in the Revista De Frormacion $Y$ Documentacion Profesional (No. $7 ; 1943$ ). It is pointed out that in the Mediterranean basin it is possible to cultivate plants from which a secretion having the characteristics of rubber has been extracted. This question attained great importance after the occupation of the Ukraine by the enemy, because large tracts there were devoted to the cultivation of koksagyz, a dandelion-like plant, from which it is claimed that fairly satisfactory rubber could be obtained; the percentage of rubber from the extract was as high as 27 . The article suggests that, if to this are added the species which can be cultivated in the Mediterranean basin, and also the synthetic rubber manufactured by the Germans at the Buna works, a possible solution of the natural rubber supply for European countries would be forthcoming.

\section{Maintenance Work in Electrical Supply}

A PAPER on "Maintenance of Distribution Plant and Mains on A.C. Networks" was read before the Institution of Electrical Engineers in London on November 10 by Messrs. F. N. Beaumont and F. A. Geary. They stated that the frequency with which apparatus should be examined, and the time to be allocated for each overhaul, are dependent on $(a)$ the design of the individual unit in relation to its electrical duties and the atmospheric conditions under which it has to operate; $(b)$ the electrical and mechanical strength of the materials employed; (c) the accessibility of the parts requiring normal inspection and testing ; and $(d)$ the physical lay-out and housing of the units, together with the facilities available for carrying out routine maintenance on site. The closest co-operation between the designer and the maintenance engineer is at all times desirable, in order that those details in design which require excessive maintenance may be suitably modified. It is the function of a maintenance engineer to organize the necessary maintenance, examination and testing of all sections of plant under his control, so that the plant may carry out its functional operation successfully and incipient faults be found and eradicated before they lead to failure on the line. The aspects and items of equipment dealt with in the paper are as follows. Staffing, safety precautions, record systems of plant maintenance, switchgear maintenance, batteries, transformers, transformer chambers, fire-fighting installations, protective gear and mains. The paper shows that maintenance, combined with adequate records, can foster improved design, to the mutual advantage of manufacturer and user, in order to obtain for future purposes the best design and lay-out practicable.

\section{Electricity in Mines}

A REVIEw of this subject given (J. Inst. Elect. Eng., 90, Pt. 1, No. 34 ; October 1943) by Mr. J. A. B. Horsley covers the use of electricity in mines under the Coal Mines Acts which are operative in Great Britain. The review gives certain statistical data and surveys technical developments, British Standard specifications, effect of recent legislation, and future developments.

\section{Literature of Penicillin and Similar Substances}

LAST September the National Research Council of Canada issued "Abstracts on Penicillin and other Antibiotic Substances" (National Research Council, Ottawa: No. 1160. 1.00 dollar). Compiled by Miss Muriel E. Whalley, of the Research Plans and Publications Section, it arranges by authors 185 abstracts taken from the American Chemical Abstracts (1917 to Sept. 10, 1943, inclusive) and other material found in the library of the National Research Council of Canada. An index increases the usefulness of this publication and Miss Whalley is to be congratulated on her work. The abstracts deal with the chemical and biological properties of sixteen substances in all. Eight of these are obtained from bacteria, eight from fungi. Among the latter are penicillin, penatin and fumigacin, some of the properties of which have been noted in these columns recently. The properties of patulin were made known too late to be included in Miss Whalley's very useful compilation. As we go to press we learn from the British Medical Journal (Dec. 18, 1943, p. 800) that the January number of the British Medical Bulletin will be devoted to authoritative articles on, and a bibliography of, penicillin.

\section{Rediscovery of Comet Daniel (1909 IV)}

This comet was seen by Mr. G. F. Kellaway, West Coker, on Nov. 30d. 22h., and a few nights later his photographic results confirmed the position which he had adopted for it. Its magnitude at the time of discovery was 13 , and it was very close to the place predicted by Mr. W. P. Henderson and Dr. H. Whichello, in the "Handbook of the British Astronomical Association", 1943. 